\title{
ANNOUNCEMENTS
}

\section{CONSTITUTION OF A CHAMBER OF THE INTERNATIONAL COURT OF JUSTICE FOR ENVIRONMENTAL MATTERS}

The following information has been made available by the Registry of the International Court of Justice (Communiqué No. 93/20, 19 July 1993).

The Statute of the Court provides, in Article 36, paragraph 1, as follows:

'The jurisdiction of the Court comprises all cases which the parties refer to it and all matters specially provided for in the Charter of the United Nations or in treaties and conventions in force.'

At present, out of eleven cases in its docket, the full Court is seised of two cases, namely those concerning Certain Phosphate Lands in Nauru (Nauru v. Australia) and the Gabcikovo-Nagymaros Project (Hungary/Slovakia) with important implications for international law on matters relating to the environment.

The Statute of the Court also provides, in Article 26, paragraph 1, as follows:

'The Court may from time to time form one or more chambers, composed of three or more judges as the Court may determine, for dealing with particular categories of cases; for example, labour cases and cases relating to transit and communications.'

In the past the Court has considered the question of the possible formation of a chamber to deal with environmental matters. On those occasions it took the view that it was not yet necessary to set up a standing special chamber, emphasizing that it was able to respond rapidly to requests for the constitution of a socalled ' $a d$ hoc' Chamber (pursuant to Article 26, paragraph 2 of the Statute) which could deal also with any environmental case.

In view of the developments in the field of environmental law and protection which have taken place in the last few years, and considering that it should be prepared to the fullest possible extent to deal with any environmental case falling within its jurisdiction, the Court has now deemed it appropriate to establish a seven-member Chamber for Environmental Matters composed as follows: Judges Schwebel, Bedjaoui, Evensen, Shahabuddeen, Weeramantry, Ranjeva and Herczegh.

The Members of the Chamber, who have been elected by secret ballot, will serve for an initial period of six months and will enter upon their duties on 6 August 1993. 


\section{T.M.C. ASSER INSTITUUT WORKSHOP, 10 DECEMBER 1993}

On 10 December 1993 the T.M.C. Asser Instituut (Institute for Private and Public International Law, International Commercial Arbitration and European Law) will hold a workshop on the 'Outline for a General Act on Private International Law' which was published by the Private International Law Legislation Department of the Netherlands Ministry of Justice in August 1992. This workshop is intended to contribute to the academic discussion on the aims, methods and certain other topics related to the outline.

The workshop Chairman will be Prof. A.V.M. Struycken and the following subjects will be discussed:

- The structure and methodology of the Outline in general Rapporteur: Prof. M.V. Polak

Reporter: Prof. K. Siehr

- The general exception clause of Art. 8 of the Outline Rapporteur: Prof. J.C. Schultsz Reporter: Prof. A.E. von Overbeck

- Arts. 91-100 of the Outline, the law appropriate to non-contractual obligations

Rapporteur: Prof. H.U. Jessurun d'Oliveira

Reporter: Prof. J. Erauw

- Procedural aspects of the Outline

Rapporteur: Prof. P. Vlas

Reporter: Prof. $H$. van Houtte

The workshop will be held in the Van Kleffen room at the Ministry of Foreign Affairs, Bezuidenhoutseweg 67, The Hague. It will commence at 9.30 a.m. The working language of the workshop will be Dutch. The number of places available will be limited. Further information on the workshop, the fees payable on attendance and requests for application forms, etc., may be obtained from the T.M.C. Asser Instituut's Private International Law Department, tel.: 0703420330, Monday-Friday between 9 a.m. and 12, or by post: T.M.C. Asser Instituut, P.O. Box 30461, 2500 GL The Hague. 